\title{
Structural, morphological and magnetic characters of PVP coated $\mathrm{ZnFe}_{2} \mathrm{O}_{4}$ nanoparticles
}

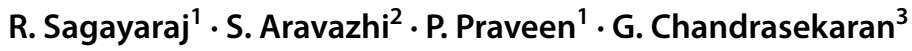

Received: 1 July 2017 / Accepted: 23 October 2017 / Published online: 14 November 2017

(c) The Author(s) 2017. This article is an open access publication

\begin{abstract}
The most stable and magnetic recoverable material $\mathrm{XY}_{2} \mathrm{Z}_{4}(\mathrm{X}=\mathrm{Zn}, \mathrm{Y}=\mathrm{Fe}$ and $\mathrm{Z}=\mathrm{O})$ having spinel ferrite nanoparticles were synthesized by chemical co-precipitation technique using polyvinyl pyrrolidone (PVP) as the surfactant. The synthesized nanoparticles were characterized by using various characterization techniques. The X-ray diffraction (XRD) analyses revealed that, the $\mathrm{ZnFe}_{2} \mathrm{O}_{4}$ have normal spinel structure of phase pure polycrystalline in nature. The FT-IR analysis revealed that the two prestigious vibration bands recorded near $\left(540-550 \mathrm{~cm}^{-1}\right)$ and $\left(455-470 \mathrm{~cm}^{-1}\right)$ show the presence of tetrahedral and octahedral voids in zinc ferrite. The transmission electron microscopy (TEM) photographs showed the synthesized $\mathrm{ZnFe}_{2} \mathrm{O}_{4}$ nanoparticles are spherical in shape and has magnetic domain structure. The vibrating sample magnetometer (VSM) spectra indicated that the prepared $\mathrm{ZnFe}_{2} \mathrm{O}_{4}$ nanoparticles exhibited super paramagnetic behavior along with high saturation magnetization at room temperature. Such synthesis $\mathrm{ZnFe}_{2} \mathrm{O}_{4}$ nanoparticles with sympathetic size and tunable magnetic properties are used for various promising biomedical applications.
\end{abstract}

\section{Introduction}

Ferrimagnetic (ferrites) materials are the salt of some of the transition metals, particularly which crystallize in spinel structure. Ferrite nanoparticles with spinel lattice are one of the most vital and fast-growing areas of the scientists and researchers interest. The spinel ferrites have excellent potential applications in many fields, such as satellite communication, memory storage devices, filters circuit, microwave fascinating materials, computer machinery, satellite dish rod, magnetic soundtrack, transformer cores, high-frequency systems, electronic circuits power delivering devices, electromagnetic interference suppression, cancer disease treatment and magnetic resonance imaging [1]. In general, the molecular formula of ferrites can be written as $\mathrm{XY}_{2} \mathrm{Z}_{4}$, where $\mathrm{X}$ is the tetrahedral voids and $\mathrm{Y}$ is the octahedral sites. Here,

S. Aravazhi

ara_vazhi@yahoo.co.in

1 PG \& Research Department of Physics, St. Joseph's College of Arts and Science (Autonomous), Cuddalore 607001, Tamil Nadu, India

2 Department of Physics, Arignar Anna Gov. Arts College, Villupuram 605602, Tamil Nadu, India

3 Department of Physics, Pondicherry University, Pondicherry 605014, India
$\mathrm{X}^{2+}$ is the divalent positive metal ion similar to $\mathrm{Fe}, \mathrm{Co}, \mathrm{Zn}$, $\mathrm{Ni}, \mathrm{Mg}, \mathrm{Mn}$ etc., $\mathrm{Y}^{3+}$ is a trivalent cation like $\mathrm{In}, \mathrm{Al}, \mathrm{Ti}, \mathrm{V}$, $\mathrm{Cr}, \mathrm{Co}, \mathrm{Fe}, \mathrm{Ni}$ etc. and $\mathrm{Z}^{2-}$ is generally the divalent oxygen ion. As an important member of ferrite family, zinc ferrite $\left(\mathrm{ZnFe}_{2} \mathrm{O}_{4}\right)$ has attracted significant research interest due to their distinctive structural and magnetic properties. $\mathrm{ZnFe}_{2} \mathrm{O}_{4}$ is a chemically and thermally stable semiconductor material [2]. As one of the magnetic materials, bulk $\mathrm{ZnFe}_{2} \mathrm{O}_{4}$ has a normal spinel structure with the tetrahedral $\left(\mathrm{X}^{2+}\right)$ sites occupied by $\mathrm{Zn}^{2+}$ and the octahedral $\left(\mathrm{Y}^{3+}\right)$ sites occupied by $\mathrm{Fe}^{3+}$ [3]. However, in the "inverse" spinel structure, more common in spinel ferrites, $\mathrm{X}^{2+}$ cations are replaced by half of $\mathrm{Fe}^{3+}$ ions in the tetrahedral sites and the second half of $\mathrm{Fe}^{3+}$ ions remaining at the octahedral sites $[4,5]$. In general, the relative sizes of $\mathrm{X}^{2+}$ and $\mathrm{Y}^{3+}$, understand of the smaller positive ion prefer to occupy the site of lower coordination i.e., tetrahedral site. And the bigger positive ions prefers to occupy the site of higher coordination i.e., octahedral sites. The structures of spinels are affected by the relative ligandfield stabilization energy (LFSE) values of metal ions. These LFSE values of $\mathrm{Y}^{3+}$ positive ions in octahedral sites greater than $\mathrm{X}^{2+}$ ions in tetrahedral sites. The difference in LFSE value between the octahedral and tetrahedral is referred to as octahedral site stabilization energy (OSSE). If the $\mathrm{Y}^{3+}$ ions have more coordination-field stabilization energy (CFSE) gain in the octahedral site than that of $\mathrm{X}^{2+}$ ions, a normal 
spinel is expected. Whereas, an inverse spinel is formed whenever the divalent $\mathrm{X}^{2+}$ ions have comparatively more CFSE gain in the octahedral geometry than the trivalent $\mathrm{Y}^{3+}$ ions. A normal spinel structure is assumed if both the divalent and the trivalent metals are non-transition metals since no CFSE is involved. And, the formation of inverse spinel structure in some cases which contain transition metal ions. This is because, the transition metal ion may get extra stability in octahedral sites, prefers octahedral voids over tetrahedral voids. $\mathrm{Fe}_{3} \mathrm{O}_{4}$ is an inverse spinel since the $\mathrm{Fe}^{3+}$ ions is a high spin $\mathrm{d}^{5}$ system with zero CFSE while, the divalent $\mathrm{Zn}^{2+}$ is a high spin $\mathrm{d}^{6}$ system with more CFSE. Hence, $\mathrm{ZnFe}_{2} \mathrm{O}_{4}$ is a normal spinel because both the divalent and trivalent ions are non- transition metal ions. In this present study, PVP functionalized $\mathrm{ZnFe}_{2} \mathrm{O}_{4}$ nanoparticles were synthesized using chemical co-precipitation route. Then, the structure, morphology and magnetic domains of $\mathrm{ZnFe}_{2} \mathrm{O}_{4}$ nanoparticles were investigated by $\mathrm{X}$-ray diffraction analysis (XRD), Fourier transform infrared spectroscopy (FT-IR), Transmission electron microscopy (TEM) with energy dispersive X-ray (EDX) analysis and Vibrating sample magnetometer (VSM).

\section{Experimental section}

\subsection{Materials}

Ferric sulfate monohydrate [ $\mathrm{Fe}_{2}\left(\mathrm{SO}_{4}\right)_{3} \cdot \mathrm{H}_{2} \mathrm{O}$, assay: $99 \%$ ], ferrous sulfate tetra hydrate $\left[\mathrm{Fe}\left(\mathrm{SO}_{4}\right) \cdot 7 \mathrm{H}_{2} \mathrm{O}\right.$, assay: $\left.98 \%\right]$, zinc sulfate hepta hydrate $\left[\mathrm{ZnSO}_{4} \cdot 7 \mathrm{H}_{2} \mathrm{O}\right.$, assay: $\left.98 \%\right]$, ethanol, ammonia, polyvinyl pyrrolidone $\left[\left(\mathrm{C}_{6} \mathrm{H}_{9} \mathrm{NO}\right)_{\mathrm{n}}\right.$, assay: 98\%] were purchased from Sigma-Aldrich and used without further purification.

\subsection{Synthesis of PVP coated $\mathrm{ZnFe}_{2} \mathrm{O}_{4}$ nanoparticles}

In a typical experiment, aqueous solutions of $100 \mathrm{ml}$ containing $0.017 \mathrm{M}$ of ferric sulfate, $0.033 \mathrm{M}$ of ferrous sulfate, $(\mathrm{X}=0.01,0.02,0.03$ and $0.04 \mathrm{M})$ zinc sulfate hepta hydrate and $0.0025 \mathrm{M}(1 \mathrm{~g})$ Polyvinyl Pyrrolidone (PVP) were added into $250 \mathrm{ml}$ conical flask. The mixture was stirred for 45 min to obtain a homogeneous solution and then, $0.25 \mathrm{M}$ of ammonia was dissolved in $50 \mathrm{ml}$ of distilled water. This solution was added slowly to the homogeneous mixture for maintaining the $\mathrm{P}^{\mathrm{H}}$ level at 11 . Under vigorous magnetic stirring for $3 \mathrm{~h}$ at room temperature, the solution appears black colour, this is the required condition for precipitation of the nanoparticles. These black powder was dissolved into methanol then centrifuged and separated with a bar magnet. This process was continually repeated for 4 times in order to remove the excess amine molecules. We get a black powder of $\mathrm{ZnFe}_{2} \mathrm{O}_{4}$ after drying the precipitate at
$100{ }^{\circ} \mathrm{C}$ for $6 \mathrm{~h}$. The dried powder was kept at muffle furnace and annealed at $600{ }^{\circ} \mathrm{C}$ for $4 \mathrm{~h}$, in order to obtain phase pure $\mathrm{ZnFe}_{2} \mathrm{O}_{4}$ nanoparticles.

\section{Results and discussion}

\subsection{Structural analysis}

From XRD graph (Fig. 1), it is evident that there is no detectable trace of extra peaks corresponds to impurity and amorphous phase in the patterns. For a small amount of $\mathrm{Zn}$ doped with $\mathrm{Fe}_{3} \mathrm{O}_{4}$, it affects the tetrahedral and octahedral structure, on the other hand, magnetic properties increases. On increasing the doping ratio in terms of $0.01 \mathrm{mg}$, the $\mathrm{Zn}^{2+}$ ions promoted to grain growth while the grains evolving from spherical smooth surfaces with peaks become sharper. Beyond the concentration, it has been noticed that there is an increment in grain size may be due to an increase in the density of the pores. The crystallite size decreases significantly when the sintering temperature reaches around $600{ }^{\circ} \mathrm{C}$ with different doping ratio of $\mathrm{Zn}^{2+}$ ion, due to that $\mathrm{Zn}^{2+}$,

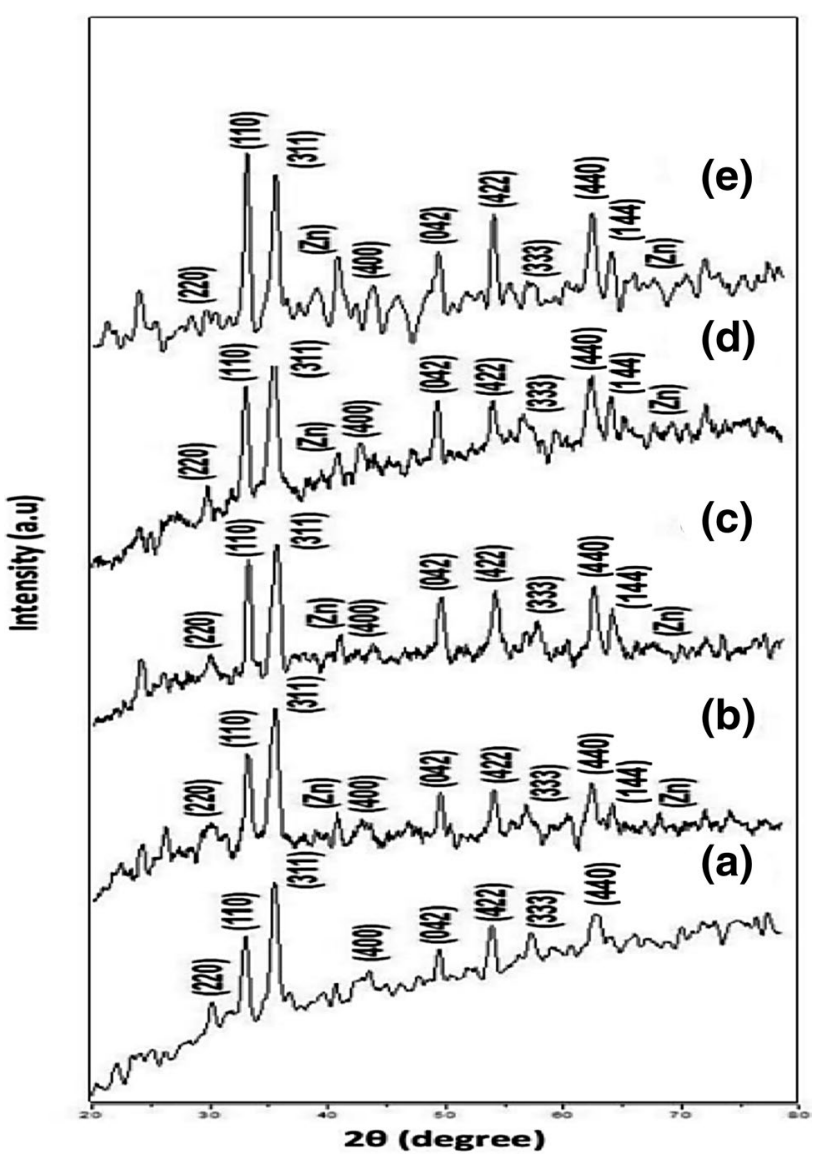

Fig. 1 XRD patterns of $a \mathrm{Fe}_{3} \mathrm{O}_{4}, b \mathrm{Zn}_{0.01}{ }_{\mathrm{M}} \mathrm{Fe}_{2} \mathrm{O}_{4}, c \mathrm{Zn}_{0.02}{ }_{\mathrm{M}} \mathrm{Fe}_{2} \mathrm{O}_{4}, d$ $\mathrm{Zn}_{0.03} \mathrm{M}_{2} \mathrm{Fe}_{2} \mathrm{O}_{4}$ and $e \mathrm{Zn}_{0.04}{ }_{\mathrm{M}} \mathrm{Fe}_{2} \mathrm{O}_{4}$ nanoparticles 
$\mathrm{Fe}^{3+}$ cations shared between tetrahedral and octahedral voids, respectively. Since, the ionic radius of $\mathrm{Zn}^{2+}(74 \mathrm{pm})$ is greater than $\mathrm{Fe}^{3+}(60 \mathrm{pm})$ ion [3]. So, the $\mathrm{ZnFe}_{2} \mathrm{O}_{4}$ nanoparticles exhibit normal spinel structure. The crystallite size of the sample $(11.14 \mathrm{~nm})$ is estimated using Scherrer's equation [2],

$\mathrm{D}=0.9 \lambda / \beta \cos \theta$

where $\lambda, \beta$ and $\theta$ be the $\mathrm{X}$-ray wavelength, the full width of half maximum (FWHM) of the peak, the Bragg angle, respectively. All the observed peaks were indexed to cubic Zn-ferrite spinel structure using JCPDS data (Card No: 87-0713). The reflections (220), (110), (311), (400), (024), (422), (333), (440) and (144) showed that the formation of single phase cubic normal spinel structure. The lattice parameter was calculated by using the following relation [5],

$\mathrm{a}=\left[\mathrm{d}^{2}\left(\mathrm{~h}^{2}+\mathrm{K}^{2}+\mathrm{l}^{2}\right)\right]^{1 / 2}$.

A lattice constant deals with physical dimension of all crystal systems and structure of magnetic materials. The composition, crystallite size and lattice constant for all the samples are summarized in Table 1. From this table, the average lattice constant is $\sim 8.4 \AA$. It is revealed that the nanoparticles may have cubic structure because of all the values of lattice constants (a) are almost equal. We conclude from the above said analysis that the structural length lies between tetrahedral and octahedral sites within the unit cell. Therefore, the $\mathrm{Zn}$ materials are grown on the Fe materials may lead to the super paramagnetic behavior of an entire system.

\subsection{Functional group analysis}

The FT-IR spectroscopy indicates the positions of the ions involved in the crystal lattice through their vibration modes. The spectra as shown in Fig. 2 were recorded at room temperature in the frequency range between 4000 and $400 \mathrm{~cm}^{-1}$. The shift in the band position was observed by increasing $\mathrm{Zn}^{2+}$ concentration in $\mathrm{Fe}_{3} \mathrm{O}_{4}$ because of the variation in the

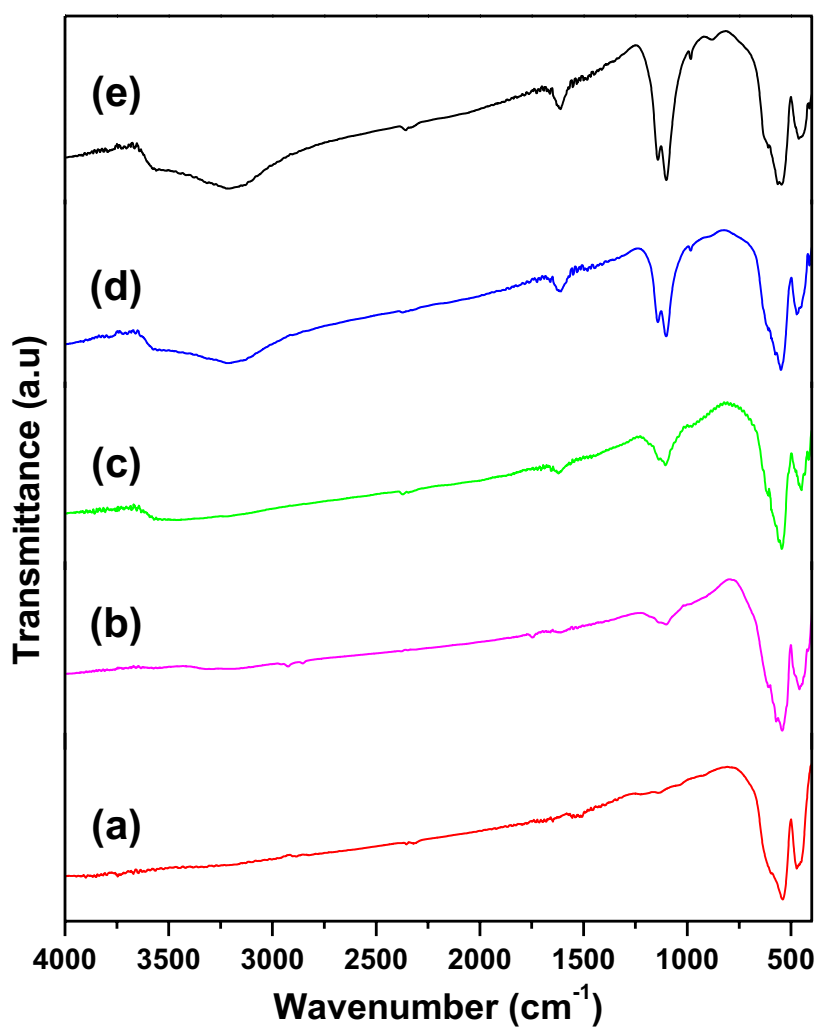

Fig. 2 FTIR spectra of $a \mathrm{Fe}_{3} \mathrm{O}_{4}, b \mathrm{Zn}_{0.01}{ }_{\mathrm{M}} \mathrm{Fe}_{2} \mathrm{O}_{4}, c \mathrm{Zn}_{0.02}{ }_{\mathrm{M}} \mathrm{Fe}_{2} \mathrm{O}_{4}, d$ $\mathrm{Zn}_{0.03}{ }_{\mathrm{M}} \mathrm{Fe}_{2} \mathrm{O}_{4}$, and $e \mathrm{Zn}_{0.04}{ }_{\mathrm{M}} \mathrm{Fe}_{2} \mathrm{O}_{4}$ nanoparticles

cation-oxygen bond length at the octahedral $\left(\mathrm{Y}^{3+}\right)$ and tetrahedral sites $\left(\mathrm{X}^{2+}\right)$. This may be interpreted by the stronger binding of $\mathrm{Fe}^{3+}$ ions at the $\mathrm{X}$-sites than at the $\mathrm{Y}$-sites. The bands between 3563 and $3218 \mathrm{~cm}^{-1}$ could be attributed to the $\mathrm{O}-\mathrm{H}$ stretching vibration of $\mathrm{H}_{2} \mathrm{O}$ absorbed by the sample [6] and the bands at $1112-1100 \mathrm{~cm}^{-1}$ ascribed for $\mathrm{C}-\mathrm{H}$ bending mode. The peaks with a wave number of 1101 and $1102 \mathrm{~cm}^{-1}$, are due to stretching vibration of $\mathrm{C}-\mathrm{O}$ bond $[7$, 8]. The bands at 1618 and $1619 \mathrm{~cm}^{-1}$ correspond to the asymmetric stretching vibrations of $\mathrm{C}=\mathrm{O}$ bond [9]. The peaks at $2924 \mathrm{~cm}^{-1}$ are due to stretching vibrations of $\mathrm{C}=\mathrm{H}$ bond of the $\mathrm{CH}_{3}$ functional group [6]. The bands in the range $457-470$ and $540-549 \mathrm{~cm}^{-1}$ correspond to the vibration of
Table 1 Structural properties of ferrite nanoparticles

\begin{tabular}{lllllll}
\hline Materials & $2 \theta(\mathrm{deg})$ & FWHM $(\beta)$ & d spacing $(\AA)$ & $\operatorname{Cos} \theta(\mathrm{deg})$ & $\begin{array}{l}\text { Crystallite } \\
\text { size }(\mathrm{nm})\end{array}$ & $\begin{array}{l}\text { Lattice } \\
\text { constant } \\
(\AA)\end{array}$ \\
\hline $\mathrm{Fe}_{3} \mathrm{O}_{4}$ & 335.45 & 0.66 & 2.52 & 0.9526 & 12.66 & 8.357 \\
$\mathrm{Zn}_{0.01} \mathrm{Fe}_{2} \mathrm{O}_{4}$ & 332.92 & 0.40 & 2.71 & 0.9588 & 20.77 & 8.988 \\
$\mathrm{Zn}_{0.02} \mathrm{Fe}_{2} \mathrm{O}_{4}$ & 335.38 & 1.00 & 2.53 & 0.9526 & 8.35 & 8.391 \\
$\mathrm{Zn}_{0.03} \mathrm{Fe}_{2} \mathrm{O}_{4}$ & 335.48 & 0.75 & 2.52 & 0.9593 & 11.14 & 8.357 \\
$\mathrm{Zn}_{0.04} \mathrm{Fe}_{2} \mathrm{O}_{4}$ & 335.35 & 0.87 & 2.53 & 0.9526 & 9.60 & 8.391 \\
\hline
\end{tabular}


the chemical $O \backslash \mathrm{M}_{\mathrm{oct}} \backslash \mathrm{O}$ bond at octahedron position and the vibration of the chemical bond $\mathrm{O} \backslash \mathrm{M}_{\mathrm{tet}} \backslash \mathrm{O}$ at tetrahedron position, respectively [10] and all the frequencies data are showed in Table 2.

\subsection{Morphological analysis}

Figures 3 and $4 \mathrm{a}, \mathrm{b}$ depict TEM photographs of $\mathrm{Fe}_{3} \mathrm{O}_{4}$ and $\mathrm{Zn}_{\mathrm{x}} \mathrm{Fe}_{2} \mathrm{O}_{4}(\mathrm{x}=0.03 \mathrm{M})$, nanoparticles, respectively. The TEM images show that the particles with the nearly spherical shape having sizes in the range between 20 and $50 \mathrm{~nm}$. These particles are found to be stacked on top of each other due to their mutual magnetic attraction. The observed particle sizes were consistent with the crystallite size determined by the XRD technique. The selected area electron diffraction (SAED) analysis of the distinctive samples was shown in Figs. 3 and 4c. The SAED patterns specify that the $\mathrm{Zn}^{2+}$ substituted ferrite nanoparticles were originated in well-crystalline nature. The super imposition of the bright spot with Debye ring pattern focused on polycrystalline nature of the samples. Chemical purity and stoichiometry of the $\mathrm{Fe}_{3} \mathrm{O}_{4}$ and $\mathrm{ZnFe}_{2} \mathrm{O}_{4}$ nanoparticles were investigated by EDAX spectroscopy. The strong peaks related to $\mathrm{Fe}, \mathrm{Zn}$ and $\mathrm{O}$ were found in the Figs. 3 and 4d. The EDAX results also confirmed that the precursors used in the synthesis have fully undergone the chemical reaction to form the single phase nanocrystalline zinc ferrite as shown in Tables 3, 4.

\subsection{Magnetic characterization}

The magnetic properties are the most important properties of ferrites, which are depending on the processing conditions, nanostructure, chemical composition and the type of the additives. Figure 5 shows a typical M-H diagram for (a) $\mathrm{Fe}_{3} \mathrm{O}_{4}$ and (b) $\mathrm{ZnFe}_{2} \mathrm{O}_{4}$ nanoparticles. As the applied field is increased to a positive value large enough to saturate the polarization of the material, $\mathrm{M}$ (moments) then reduced to a negative value large enough to produce saturation in the reverse direction then increased back to zero once again. A symmetrical closed loop known as hysteresis is thus formed. The magnetic induction is remaining when the applied field is reduced from saturation to zero is called the remnant $\left(\mathrm{M}_{\mathrm{r}}\right)$. Here, the retentivity value of $\mathrm{ZnFe}_{2} \mathrm{O}_{4}$ is $571.58 \mathrm{E}-6 \mathrm{emu}$. This magnetic retentivity results showed that the $\mathrm{ZnFe}_{2} \mathrm{O}_{4}$ nanoparticles annealed at $600{ }^{\circ} \mathrm{C}$ temperature exhibit, decreased hysteresis loop area when an increase of $\mathrm{Zn}^{2+}$ ions. The saturation magnetization $\left(\mathrm{M}_{\mathrm{s}}\right)$ increases into $23.451 \mathrm{E}-3 \mathrm{emu}$ and then particle size is calculated to be $11.14 \mathrm{~nm}$ (from XRD). This shows that the $\mathrm{ZnFe}_{2} \mathrm{O}_{4}$ is normal spinel, with $\mathrm{Zn}^{2+}$ in tetrahedral sites and $\mathrm{Fe}^{3+}$ in octahedral sites with anti-parallel arrangement of magnetic moments of super paramagnetic materials. Hence, the magnetization behavior depends on the crystallite size and cation distribution. The most common characteristic of fumets is their super-paramagnetic behavior and the decrease of the saturation magnetization in comparison to the related bulk material $\left(55 \mathrm{emu} \mathrm{g}^{-1}\right)$. The average crystallite size was $12 \mathrm{~nm}$ and the magnetic saturation $\left(\mathrm{M}_{\mathrm{s}}\right) 41.70 \mathrm{emu} \mathrm{g}^{-1}$ [11]. For the present system, the values of remanence magnetization $\left(\mathrm{M}_{\mathrm{r}}\right)$ decreases from 17 to $10 \mathrm{emu} \mathrm{g}^{-1}$ with increasing $\mathrm{Zn}^{2+}$ substitution The remnant ratio $(\mathrm{R})=\mathrm{M}_{\mathrm{r}} / \mathrm{M}_{\mathrm{s}}$ is a characteristic parameter of a material. Higher and lower remnant ratios denote different material responses and accordingly determine where the material will be applied. It is desirable to have higher remnant ratios for magnetic recording and memory devices [12]. The magnetic moment $(\mu \mathrm{B})$ per atom in Bohr magneton for each sample is calculated using the following equation and represented in Table 5.

$\mu \mathrm{B}=\mathrm{M} \times\left[\mathrm{M}_{\mathrm{S}} / 5585\right]$

where $\mathrm{M}$ is molecular weight of $\mathrm{ZnFe}_{2} \mathrm{O}_{4}$ [13].

\section{Conclusions}

In summary, a simple and economical che mical co precipitation method to synthesize $\mathrm{ZnFe}_{2} \mathrm{O}_{4}$ nanoparticles has been

Table 2 Tentative vibrational assignments of ferrite nanostructures

\begin{tabular}{|c|c|c|c|c|c|}
\hline \multicolumn{5}{|c|}{ Frequencies $\left(\mathrm{cm}^{-1}\right)$} & \multirow[t]{2}{*}{ Tentative vibrational assignments } \\
\hline $\mathrm{Fe}_{3} \mathrm{O}_{4}$ & $\mathrm{Zn}_{0.01 \mathrm{M}} \mathrm{Fe}_{2} \mathrm{O}_{4}$ & $\mathrm{Zn}_{0.02 \mathrm{M}} \mathrm{Fe}_{2} \mathrm{O}_{4}$ & $\mathrm{Zn}_{0.03 \mathrm{M}} \mathrm{Fe}_{2} \mathrm{O}_{4}$ & $\mathrm{Zn}_{0.04 \mathrm{M} \mathrm{Fe}_{2} \mathrm{O}_{4}}$ & \\
\hline- & - & - & - & - & $\mathrm{O}-\mathrm{H}$ stretching \\
\hline- & - & - & - & 3563 & \\
\hline- & - & 3775 & - & - & \\
\hline- & - & - & 1619 & 1618 & $\mathrm{C}=\mathrm{O}$ asymmetric stretching \\
\hline- & 2294 & - & - & - & $\mathrm{C}=\mathrm{H}$ stretching \\
\hline- & 1100 & 1112 & 1102 & 1101 & $\mathrm{C}-\mathrm{H}$ bending mode \\
\hline 540 & 542 & 549 & 550 & 543 & $\mathrm{O} \backslash \mathrm{M}_{\mathrm{tet}} \backslash \mathrm{O}$ bond at tetrahedron position \\
\hline 470 & 460 & 457 & 470 & 455 & $\mathrm{O} \backslash \mathrm{M}_{\mathrm{oct}} \backslash \mathrm{O}$ bond at octahedron position \\
\hline
\end{tabular}




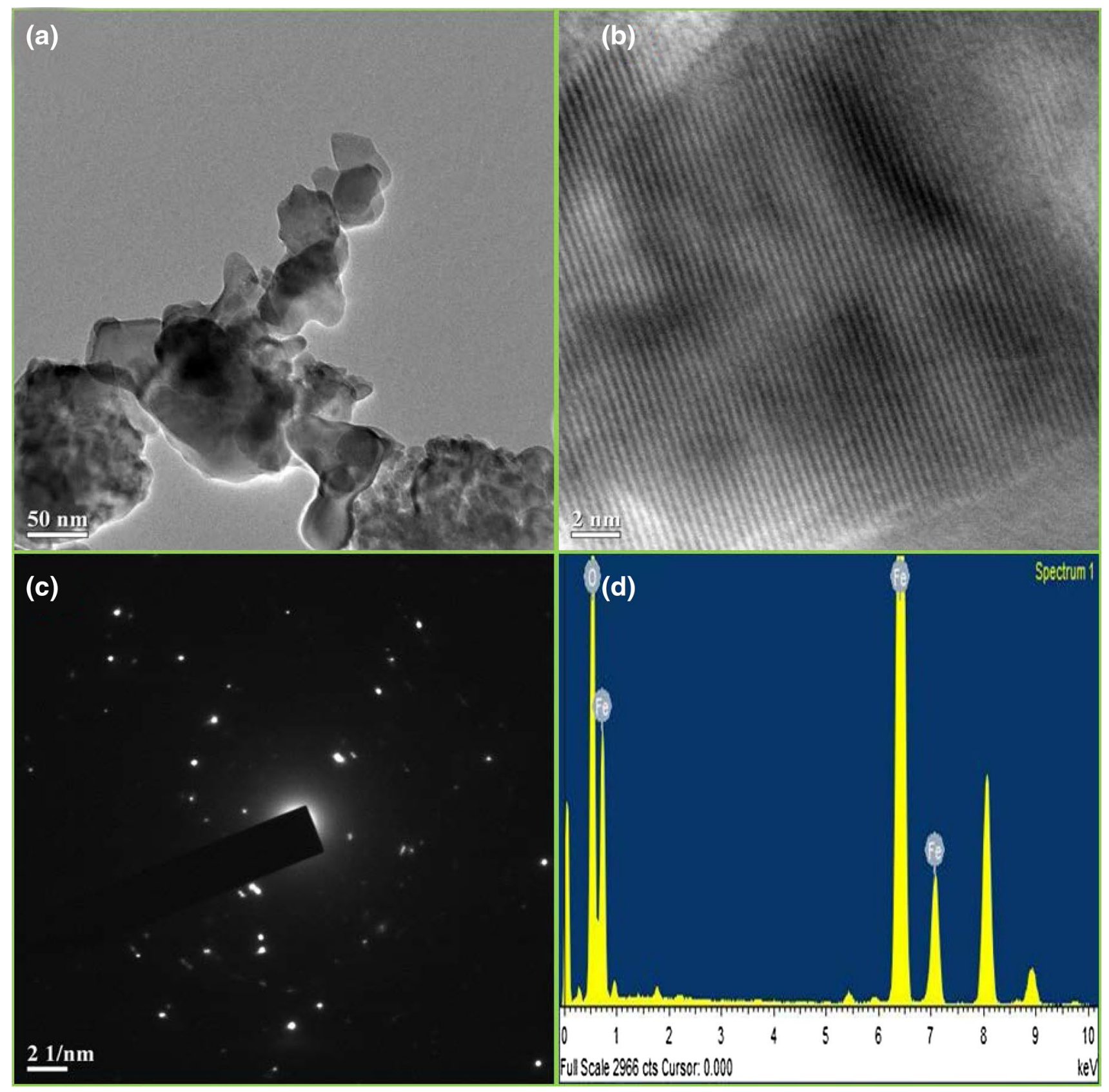

Fig. 3 a, b TEM images, $\mathbf{c}$ SAED pattern and $\mathbf{d}$ EDAX spectrum of $\mathrm{Fe}_{3} \mathrm{O}_{4}(\mathrm{x}=0.00 \mathrm{M})$ nanoparticles

developed. The prepared ferrite samples were characterized by XRD, FT-IR, TEM with EDAX and VSM analyses. The XRD patterns confirmed that the particle size of the powders annealed at $600{ }^{\circ} \mathrm{C}$ was found to be $\sim 11.14 \mathrm{~nm}$. This crystallite size was also correlated with the particle size observed from TEM images. It was found that a zinc ferrite nanoparticle has the normal spinel structure with $\mathrm{Zn}^{2+}$ and $\mathrm{Fe}^{3+}$ cations distributed between tetrahedral and octahedral sites. The TEM photographs showed that the particles having spherical shape. The SAED patterns indicated that the zinc substituted ferrites were in well -crystalline nature. The strong peaks related to $\mathrm{Fe}, \mathrm{Zn}$ and $\mathrm{O}$ were identified by the EDAX spectra. The value of coercivity $210.03 \mathrm{G}$ and saturation magnetization $23.451 \mathrm{E}-3 \mathrm{emu}$ were obtained at room temperature. The better crystallinity can improve the 


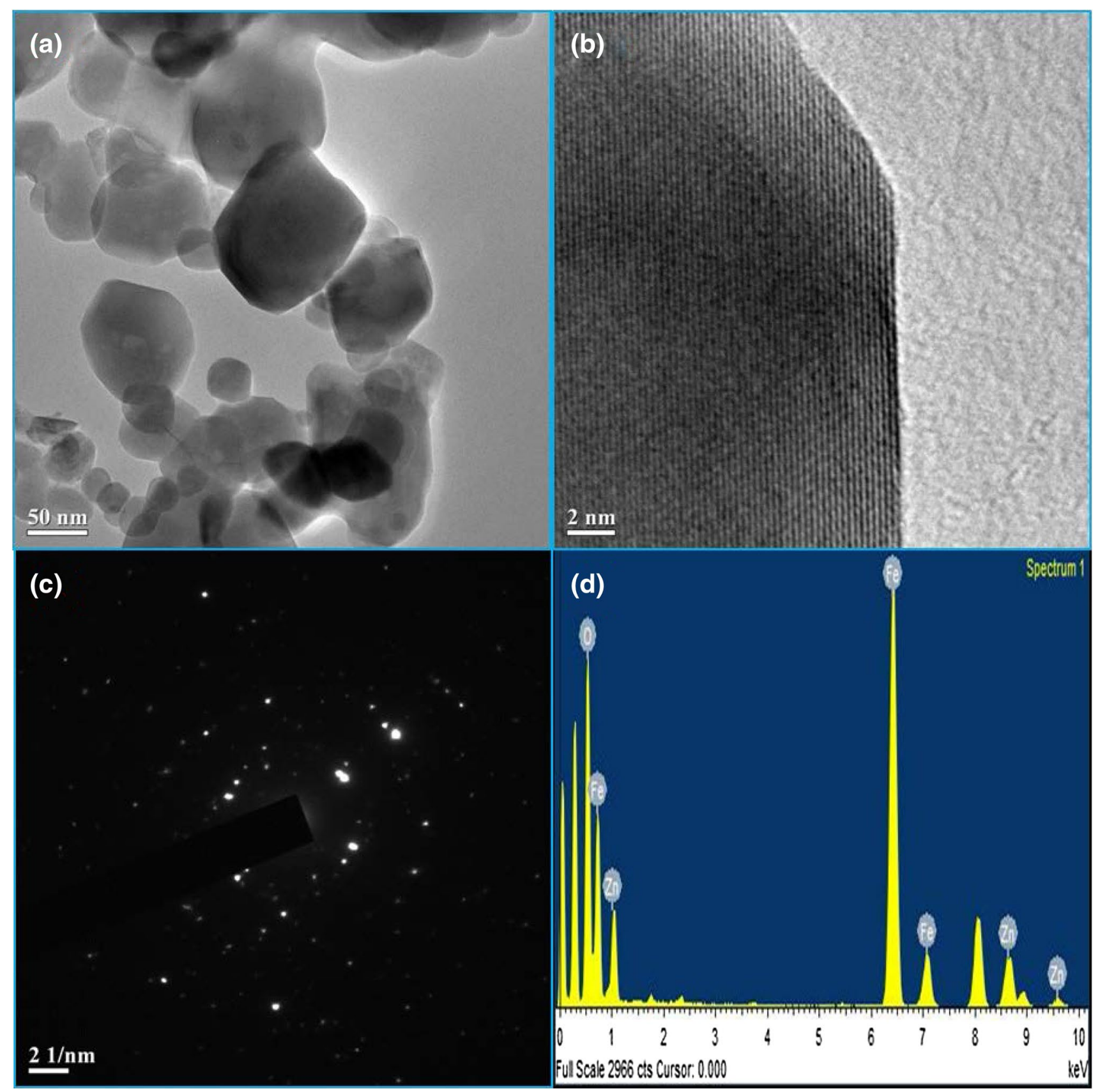

Fig. 4 a, b TEM images, $\mathbf{c}$ SAED pattern and d EDAX spectrum of $\mathrm{Zn}_{\mathrm{x}} \mathrm{Fe}_{2} \mathrm{O}_{4}(\mathrm{x}=0.03 \mathrm{M})$ nanoparticles

Table 3 EDAX spectrum analysis of $\mathrm{Fe}_{3} \mathrm{O}_{4}$ nanoparticles

\begin{tabular}{lcllllll}
\hline Element & Peak area & Area sigma & K factor & Abs Corrn. & Weight \% & Weight \% sigma & Atomic \% \\
\hline $\mathrm{O}$ & 26,252 & 311 & 1.871 & 1.000 & 28.29 & 0.26 & 57.94 \\
$\mathrm{Fe}$ & 104,542 & 516 & 1.191 & 1.000 & 71.71 & 0.26 & 42.06 \\
Total & & & & & 100 & & \\
\hline
\end{tabular}


Table 4 EDAX spectrum analysis of $\mathrm{ZnFe}_{2} \mathrm{O}_{4}$ nanoparticles

\begin{tabular}{lclllllc}
\hline Element & Peak area & Area sigma & K factor & Abs Corrn. & Weight $\%$ & Weight \% sigma & Atomic $\%$ \\
\hline $\mathrm{O}$ & 16,144 & 243 & 1.871 & 1.000 & 32.99 & 0.37 & 63.69 \\
$\mathrm{Fe}$ & 44,258 & 336 & 1.191 & 1.000 & 57.55 & 0.37 & 31.84 \\
$\mathrm{Zn}$ & 5926 & 148 & 1.462 & 1.000 & 9.46 & 0.37 & 4.47 \\
Total & & & & & 100 & &
\end{tabular}

Fig. 5 VSM images of $\mathrm{Fe}_{3} \mathrm{O}_{4}$ and $\mathrm{Zn}_{0.03} \mathrm{Fe}_{2} \mathrm{O}_{4}$ nanoparticles at room temperature
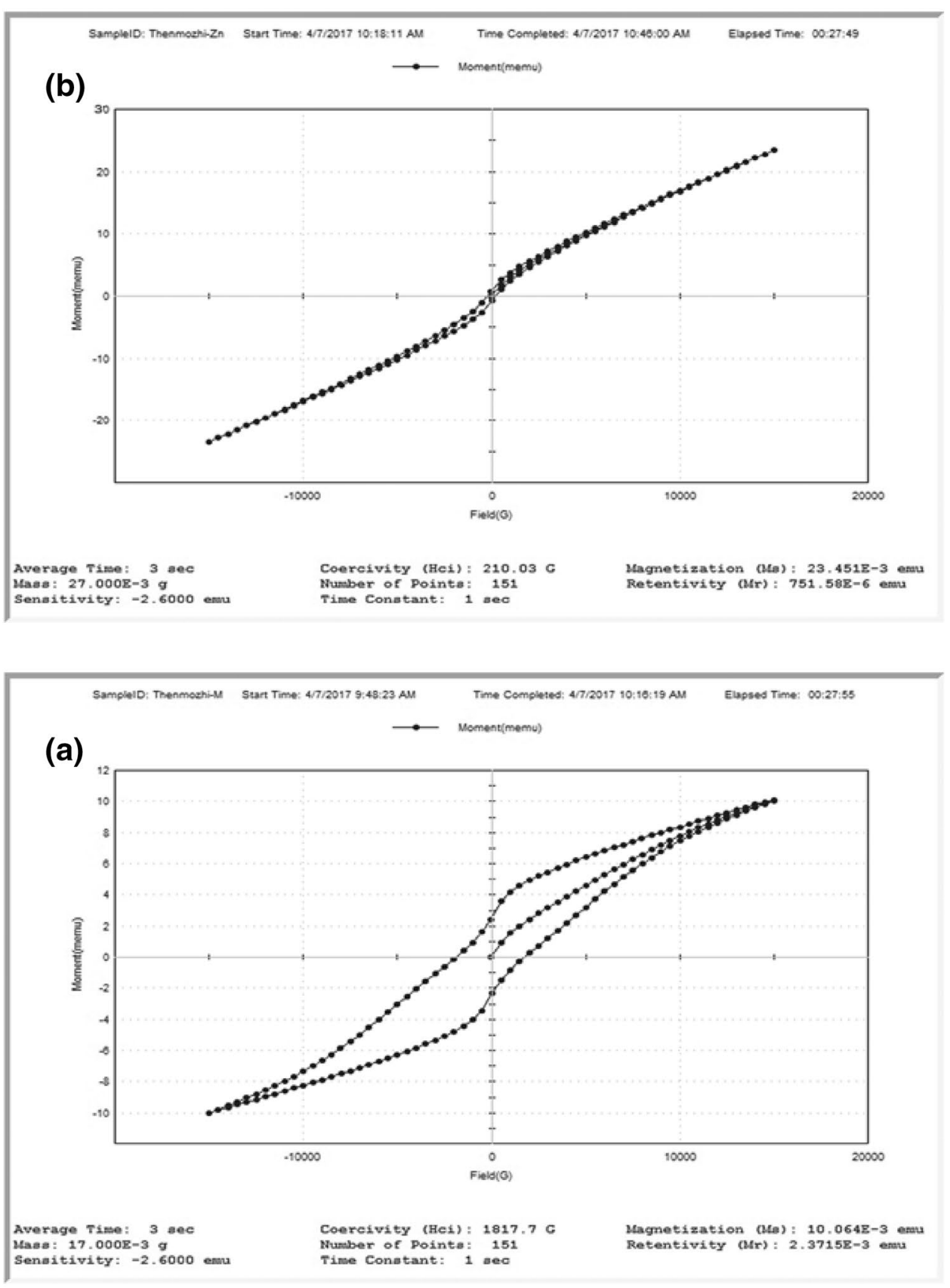
Table 5 VSM analysis of $\mathrm{Fe}_{3} \mathrm{O}_{4}$ and $\mathrm{Zn}_{0.03}{ }_{\mathrm{M}} \mathrm{Fe}_{2} \mathrm{O}_{4}$

\begin{tabular}{lllcccr}
\hline Sample & $\begin{array}{l}\text { Crystallite } \\
\text { size }(\mathrm{nm})\end{array}$ & $\mathrm{M}_{\mathrm{s}}\left(\mathrm{emu} \mathrm{g}^{-1}\right)$ & $\mathrm{M}_{\mathrm{r}}\left(\mathrm{emu} \mathrm{g}^{-1}\right)$ & $\mathrm{H}_{\mathrm{ci}}(\mathrm{Oe})$ & $\mu \mathrm{B}=\mathrm{M} \times\left[\mathrm{M}_{\mathrm{S}} / 5585\right]$ & $\mathrm{M}_{\mathrm{r}} / \mathrm{M}_{\mathrm{s}}$ \\
\hline $\mathrm{Fe}_{3} \mathrm{O}_{4}$ & 12.66 & 10.064 & 2.3715 & 1817.7 & $4.34 \times 10^{-4}$ & 0.2356 \\
$\mathrm{Zn}_{0.03} \mathrm{Fe}_{2} \mathrm{O}_{4}$ & 11.14 & 23.451 & 751.58 & 210.03 & $10.1 \times 10^{-4}$ & 32.0489 \\
\hline
\end{tabular}

saturation magnetization will opens up $\mathrm{ZnFe}_{2} \mathrm{O}_{4}$ nanoparticles have utilized for various promising applications.

Acknowledgements We remain grateful to the Administration of St. Joseph's College of Arts \& Science (Autonomous), Cuddalore, Tamilnadu, India, for providing the "Research Lab for Nanotechnology and Crystal growth" laboratory for synthesis of nonmaterials in our work.

Open Access This article is distributed under the terms of the Creative Commons Attribution 4.0 International License (http://creativecommons.org/licenses/by/4.0/), which permits unrestricted use, distribution, and reproduction in any medium, provided you give appropriate credit to the original author(s) and the source, provide a link to the Creative Commons license, and indicate if changes were made.

\section{References}

1. I.H. Gul, E. Pervaiz, Comparative study of $\mathrm{NiFe}_{2-\mathrm{x}} \mathrm{Al}_{\mathrm{x}} \mathrm{O}_{4}$ ferrite nanoparticles synthesized by chemical co-precipitation and sol-gel combustion techniques. Mater. Res. Bull. 47, 1353-1361 (2012)

2. S. Yang, D. Han, Z. Wang, Y. Liu, G. Chen, H. Luan, L. Bayanheshig, Yang, Synthesis and magnetic properties of $\mathrm{ZnFe}_{1.97} \mathrm{RE}_{0.03} \mathrm{O}_{4}$ $\left(\mathrm{RE}^{1 / 4 \mathrm{Eu}}\right.$ and $\left.\mathrm{Nd}\right)$ nanoparticles. Mater. Sci. Semicond. Process. 27, 854-859 (2014)

3. S.M. Masoudpanah, S.A. Seyyed Ebrahimi, M. Derakhshani, S.M. Mirkazemi, Structure and magnetic properties of La substituted $\mathrm{ZnFe}_{2} \mathrm{O}_{4}$ nanoparticles synthesized by sol-gel autocombustion method. J. Magn. Magn. Mater. 370, 122-126 (2014)

4. S.A. Seyyed Ebrahimi, S.M. Masoudpanah, Effects of $\mathrm{pH}$ and citric acid content on the structure and magnetic properties of $\mathrm{Mn}-\mathrm{Zn}$ ferrite nanoparticles synthesized by a sol-gel autocombustion method. J. Magn. Magn. Mater. 357, 77-81 (2014)
5. M. Ben Ali, K. El Maalam, H. El Moussaoui, O. Mounkachi, M. Hamedoun, ,R. Masrour, E.K. Hlil, A. Benyoussef, Effect of zinc concentration on the structural and magnetic properties of mixed $\mathrm{Co}-\mathrm{Zn}$ ferrites nanoparticles synthesized by sol/gel method. J. Magn. Magn. Mater. 398, 20-25 (2016)

6. A. Ghasemi, S. Ekhlasi, M. Mousavini, Effect of Cr and Al substitution cations on the structural and magnetic properties of $\mathrm{Ni}_{0.6} \mathrm{Zn}_{0.4} \mathrm{Fe}_{2 \mathrm{x}} \mathrm{Cr}_{\mathrm{x} / 2} \mathrm{Al}_{\mathrm{x} / 2} \mathrm{O}_{4}$ nanoparticles synthesized using the sol-gel auto-combustion method. J. Magn. Magn. Mater. 354, 136-145 (2014)

7. M. Khairy, Synthesis, characterization, magnetic and electrical properties ofpolyaniline/ $\mathrm{NiFe}_{2} \mathrm{O}_{4}$ nanocomposite. Synth. Met. 189, 34-41 (2014)

8. M. Asghari, A. Ghasemi, E. Paimozd, A. Morisako, Evaluation of microwave and magnetic properties of substituted $\mathrm{SrFe}_{12} \mathrm{O}_{19}$ and substituted $\mathrm{SrFe}_{12} \mathrm{O}_{19}$ /multi-walled carbon nanotubes nanocomposites. Mater. Chem. Phys. 143, 161-166 (2013)

9. L. Khanna, N.K. Verma, Size-dependent magnetic properties of calcium ferrite nanoparticles. J. Magn. Magn. Mater. 336, 1-7 (2013)

10. K. Nadeem, F. Zeba, M.A. Abid, M. Mumtaz, M. Anis ur Rehman, Effect of amorphous silica matrix on structural, magnetic, and dielectric properties of cobalt ferrite/silica nanocomposites. J. Non-Cryst. Solids 400, 45-50 (2014)

11. P. Sivakumar, R. Ramesh, A. Ramanand, S. Ponnusamy, C. Muthamizhchelvan, Synthesis, studies and growth mechanism of ferromagnetic $\mathrm{NiFe}_{2} \mathrm{O}_{4}$ nanosheet. Appl. Surf. Sci. 258, 6648-6652 (2012)

12. M. Hashim, Alimuddin, S Kumar, S.E. Shirsath, R.K. Kotnala, J. Shah, R. Kumar, Synthesis and characterizations of Ni-2p substituted cobalt ferrite nanoparticles. Mater. Chem. Phys. 139, 364-374 (2013)

13. T. Prabhakaran, J. Hemalatha, Chemical control on the size and properties of nano $\mathrm{NiFe}_{2} \mathrm{O}_{4}$ synthesized by sol-gel autocombustion method. Ceram. Int. 40, 3315-3324 (2014) 